\title{
A Critical Analysis of the Vocabulary in L2 Spanish Textbooks
}

\author{
Ma DOLORES LÓPEZ-JiMÉNEZ \\ Universidad Pablo de Olavide (Sevilla)
}

Received: 21 November 2012 / Accepted: 17 December 2012

ISSN: $1697-7467$

\begin{abstract}
This study researches the treatment given to L2 vocabulary in Spanish language textbooks. To that end, 12 textbooks (together with the teacher's editions) at three proficiency levels were analyzed. The results suggest that the vocabulary to be taught lacks consistency as the selection and grading criteria are not explicitly stated in most of the teacher's guides. The place of publication and the proficiency level of the textbooks influence the introduction of new words. Vocabulary teaching tends to be rather traditional since its practice is mostly comprised of closed and open exercises and vocabulary learning strategies are rarely present. Finally, the results of research into L2 vocabulary learning have not been taken into consideration. This can be seen in the overuse of semantic sets and the insufficient recycling found in the teaching units.
\end{abstract}

Keywords: L2 Spanish textbooks, vocabulary, introduction, practice, recycling, learning strategies.

\section{Análisis crítico del vocabulario en libros de texto para la enseñanza del español como L2}

RESUMEN: Este estudio se centra en el tratamiento dado al vocabulario en libros de texto para la enseñanza del español como L2. Para ello, se analizan 12 libros (junto con el libro del profesor) pertenecientes a tres niveles de lengua. Los resultados indican que el vocabulario que se va a enseñar carece de sistematicidad, pues los criterios de selección y gradación del léxico no aparecen en la mayoría de los libros analizados. El lugar de publicación y nivel de lengua de los libros influyen en la presentación del vocabulario nuevo. La enseñanza del vocabulario tiende a ser bastante tradicional, tal y como se puede observar en la práctica del léxico, compuesta mayormente por ejercicios cerrados y abiertos, y en la casi total ausencia de estrategias de aprendizaje del vocabulario. Por último, un uso abusivo de agrupaciones semánticas junto con un reciclaje insuficiente del vocabulario sugieren que los resultados de investigaciones acerca del aprendizaje del vocabulario en L2 no se han tenido en cuenta.

Palabras clave: Libros de texto de español como L2, vocabulario, introducción, práctica, reciclaje, estrategias de aprendizaje.

\section{L2 TeXtbooks and vocabulary}

Today few teachers would seriously question the central role played by L2 textbooks as a major pedagogical resource in teaching a non-native language (L2). Over the last 30 years, L2 textbooks have been characterized by their capacity to adapt to changing situations, 
such as the introduction of new technologies, new methodological trends in L2 teaching, or the increasingly demanding requirements of the publishing market. This flexibility is largely responsible for the dominant influence that textbooks continue to have in L2 classrooms in general and in classrooms where Spanish is taught as an L2 in particular.

While the importance of the textbook as a pedagogical resource in L2 teaching has remained constant, if not increased, over the last three decades, the language components on which textbook writers concentrate have not always received the same attention in L2 teaching. In the mid 70s, Richards (1976: 76) asserts that "the teaching and learning of vocabulary have never aroused the same degree of interest within language teaching as have such issues as grammatical competence, contrastive analysis, reading, or writing." In the 80 s numerous researchers began to take an interest in vocabulary learning (e.g., Carter, 1987; McKeown and Curtis, 1987), although it was not until the following decade with the publication of two essential works, The Lexical Approach (Lewis, 1993), and Implementing the Lexical Approach (Lewis, 1997), that the central role of the lexical component was recognized. It was then explicitly claimed that language consists of grammaticalized vocabulary rather than lexicalized grammar (Lewis, 1993).

Taking into account the prominent role assumed by the L2 vocabulary in the last two decades, this article focuses on how vocabulary is taught in commercial textbooks for the teaching of Spanish as a foreign and second language. For this purpose, lexical aspects such as the selection, organization, presentation, practice, and review of vocabulary, together with other related lexical dimensions, such as the inclusion of vocabulary learning strategies and L1 glossaries in the selected textbooks are analyzed.

\section{VOCABULARY INTRODUCTION}

\subsection{Selection criteria}

Before introducing the new vocabulary, there must be a selection of the target items to be taught. Factors such as frequency of use, coverage, culture, needs, and proficiency level should be considered in their selection. Word lists based on frequency of use proliferated over the last century. However, a fairly frequent lexical unit does not necessarily correspond to a functional item. Additionally, a low frequency word may become essential if a specific semantic value cannot be conveyed by another unit. Nation (2001) claims that the most frequent 2000 words are crucial to language learning. To this point, Milton (2009) argues that its explicit teaching is worth the classroom time since they account for about $80 \%$ of text coverage, whereas the next most frequent 2000 words accounts for only $8 \%$ of coverage. From the perspective of students' needs, lexical units on word lists may appear irrelevant due to the ethnocentricity of cultural values. Students' needs may also come into conflict with their L2 proficiency level. Gairns and Redman (1986) state that textbook authors sometimes have to design L2 technical materials (e.g., language for specific purposes, such as business English) for low-level students. In this case their limited grammatical structures may constitute a serious impediment to their needs for highly technical vocabulary. The authors hold that in teaching practice students' proficiency level is given preference over their needs. 


\subsection{Organization/Arrangement}

Once the vocabulary to be taught has been identified, it can be organized in semantic and thematic sets. A semantic grouping is described as "the organization of related words and expressions [...] into a system which shows their relationship to one another. For example, kinship terms such as father, mother, brother, sister, uncle, aunt belong to a lexical field whose relevant features include generation, sex, membership of the father's or mother's side of the family, etc." (Richards and Schmidt, 2010: 345). On the other hand, in thematic arrangements words and expressions that naturally occur when discussing a given theme or topic are included. When planning a vacation, for example, words like ticket, Internet, to book, a reservation, to select, a seat, an aisle seat, meal, arrival time, gate, jet, and silver (Folse, 2004: 48) may appear. Words in a semantic clustering belong to the same part of speech, whereas in thematic sets different parts of speech are included and psychological associations between clustered words and a shared thematic concept are established (Papathanasiou, 2009). Psychological research generated by interference theory has shown that organizing the new vocabulary in semantic sets actually impedes rather than facilitates L2 learning. Interference theory (see Postman, 1961) claims that as the similarity between information to be learned and information learned before or after that information increases, the difficulty of learning that information increases too.

\subsection{Presentation Techniques}

There are numerous techniques to explicitly introduce the meanings of new lexical units in textbooks. Some of them consist of the use of synonyms, antonyms, L1 translation equivalents, written explanations, definitions, contextualized examples, and visual support. Synonyms and antonyms might become useful resources when presenting passive vocabulary. However, providing a synonym in the student's L2 may reveal some shortcomings; that is, the L2 equivalent may be unknown to the learner and rarely two items are synonymous on every occasion (Lewis and Hill, 1985). Additionally, in the case of opposites, sometimes it is not adequate to contrast a new item with an already known word, but the contexts in which the antonym functions as a true opposite word should be offered. Gairns and Redman (1986: 74) illustrate this point as follows: a new lexical unit as 'sour' may be contrasted with 'sweet' as in the sentence "sugar is sweet and lemons are sour", whereas the same opposite relationship cannot be established in 'sweet tea' versus 'sour tea'.

With regard to the use of $\mathrm{L} 1$ translation equivalents, they prevent students from coming into contact with the L2. Moreover, when translating into the students' L1 there may not be a one-to-one translation equivalent between the L1 word and the target item. Thornbury (2002) also claims that an overuse of translation may not allow the learner to develop an independent lexicon in the L2, as the target language is accessed through the student's mother tongue. L1 translation equivalents may also be present in the form of L1 glossaries. Glossaries with L1 translation equivalents were deliberately excluded from L2 vocabulary teaching as a result of the emphasis that communicative approaches laid on the use of target language in the classroom. Nonetheless, empirical studies (Laufer and Shmueli, 1997; Luppescu and Day, 1993; Prince, 1996) have revealed the effectiveness of bilingual dictionaries when learning an L2. 
Laufer and Shmueli (1997) in a study with Hebrew learners of EFL compared four ways of presenting new words: (i) words presented in lists, (ii) words in a minimal context (e.g., a sentence), (iii) words in a text, and (iv) words in an elaborate text. The word lists were accompanied by a Hebrew translation or an English synonym. In the other three modes of presentation, half of the words were translated into the students' L1 whereas the other half was provided with an explanation in English. The findings show that words with their L1 translations were remembered better than words glossed in the L2. Regarding the context effect, words introduced in lists and sentences were better retained than words presented in texts and elaborate texts. An explanation for this is that longer contexts do not promote noticing and, consequently, learning does not take place.

Prince (1996) investigated the relationship between the proficiency level of French EFL learners and two modes of introducing the new vocabulary, that is, word lists with their L1 translations and words in sentences. The analysis of the data indicates that higher proficiency learners outperformed lower proficiency students in the testing conditions. Furthermore, both groups of learners recalled more L2 words if they had been introduced with their L1 translations. In a study by Luppescu and Day (1993), half of the Japanese EFL students they tested had access to a bilingual dictionary while reading the text, whereas the other half did not. The results show that the dictionary group surpassed the no dictionary group on a test at the end of the reading. Lawley (2010) claims that bilingual word lists help learners become more autonomous as they can work independently of the teacher and the other students. This author also points out that comprehensive word lists are a useful tool for students to save time since there is no need to understand the mechanics of new exercise types.

Other verbal techniques such as written explanations and definitions expose learners to the L2 and they also require a considerable cognitive effort (Thornbury, 2002). Besides, providing a definition alone may often be insufficient for clarifying the meaning of new words. Instead, a situational presentation that includes a contextualizing scenario may be needed. Lastly, illustrations found in textbooks mainly include photographs and drawings. They are highly valuable for the teaching of concrete vocabulary (e.g., food, furniture, animals, etc.) and semantic fields related to places, professions and occupations, descriptions of people, actions, and activities (e.g., sports and verbs of movement) (Gairns and Redman, 1986), etc. In terms of implicit introduction of meaning in textbooks, many authors make use of written texts. Hulstijn (1992) found out that L2 learners after reading a passage for comprehension retained more inferred meanings than when those meanings had been presented explicitly. This author, however, advises that students are as likely to infer the incorrect meaning as the correct one. An explanation for these results may lie in the fact that context clues tend to be rather limited and unreliable predictors of word meaning (Haynes and Baker, 1993; Schatz and Baldwin, 1986). The belief that context clues are beneficial when deriving the meaning of an unfamiliar word may come from a flawed analogy with L1 acquisition (Folse, 2004).

\section{Practice}

A key dimension to take into account is vocabulary practice. Overall, research on the types of exercises that increase the retention of L2 vocabulary has been rather limited. Some of the factors that may be considered in the analysis of different types of exercises/activi- 
ties include attention, depth of processing, and number of attempts needed for retrieval. In the current literature there is no consensus on which of these factors is/are more effective regarding vocabulary acquisition. Concerning the first factor, that is, attention, Jourdenais et al. (1995) exposed second-semester L2 Spanish learners to two versions of the same text, an enhanced and an unenhanced version. In the enhanced version, the target vocabulary was underlined and printed in a different font, and in some cases the items were written in bold or shadowed. Making these items look different caused learners to pay more attention and led to a greater use of the target items.

The learning model based on depth of processing (Craik and Tulving, 1975) claims that greater learning takes place when deeper processing is required. Laufer and Hulstijn (1998) designed three different tasks and concluded that the students who were asked to write a composition in which they had to use ten target words that were accompanied by explanations and examples obtained the highest retention scores on the immediate post-test than the other two groups. The first group received a text with the boldfaced target words and their translation into the students' L1 in the margin of the text followed by multiple-choice comprehension questions. The second group took a test that included the same text and the same comprehension questions. Instead of the target words, this group had a word list that they had to use in order to fill in ten blank spaces. Each word from the list appeared with a translation and an explanation. These results made Hulstijn and Laufer (2001) formulate the Load Involvement Hypothesis. Their hypothesis states that the degree to which an L2 learner is engaged in cognitive processing does not depend on whether the given task is input- or output-based, but rather on the combination of motivational and cognitive dimensions of the task.

As for the number of word retrievals, in Laufer and Hulstijn's (1998) work writing a composition using the target words made students keep track of their meanings and constantly rearrange them to form a coherent piece of writing. In other words, building a composition requires learners to interact with any single word multiple times. As Folse $(2004,2006)$ claims, what may be a decisive factor in L2 vocabulary acquisition is not what you do with the target words but rather the number of retrievals that a learner makes of a given lexical unit.

\section{RECYCLING ${ }^{1}$}

Memory, review, and repetition take a crucial role in the complex process of learning a lexical item. Hence vocabulary recycling becomes a determinant in that process. Nation (2001: 76-77) maintains that repetition brings quantitative and qualitative benefits to vocabulary learning: "repetition is essential for vocabulary learning because there is so much to know about each word that one meeting with it is not sufficient to gain this information, and because vocabulary items must not only be known, they must be known well so that they

\footnotetext{
${ }^{1}$ In this study vocabulary practice and recycling have been considered two distinct stages within L2 lexical teaching and learning since the practice itself does not necessarily involve already (introduced and) practiced target items as it is the case of vocabulary review.
} 
can be fluently accessed". Nation (2001) differentiates among intervals, types, and number of exposures. According to Pimsleur's (1967) memory hypothesis, after the first encounter with the new word, continued reviewing at increasingly larger intervals is necessary. Research (see Anderson and Jordan, 1928; Griffin, 1992; Seibert, 1927) reveals that word knowledge tends to fade from the learner's memory right after the first exposure and this does not occur at subsequent encounters. Learning by repetition not only depends on the intervals of the reencounters but also on the nature of the repetition itself. Thus, elaborate repetitions (e.g., providing lexical collocations) lead to greater benefits in comparison to further encounters where the same information from the first exposure is given (Stahl and Fairbanks, 1986).

With respect to the number of exposures ${ }^{2}$ needed to learn an L2 lexical unit, there is no consensus among researchers. Saragi, Nation, and Meister (1978) estimate that repetition accounts for $20 \%$ of all the factors involved in learning a new word. In their study, they concluded that the subjects required 16 or more repetitions to add a new word to their lexicon. Kachroo (1962) calculated that seven or more encounters with the same word in the textbook were necessary, so that most of the students could learn it. However, half of the words appeared solely once or twice in the textbook and consequently were not learned by the majority of the class. Paribakht and Wesche (1997) maintain that the probability of learning a new word after only one encounter is between $5 \%$ and $10 \%$.

\section{LeARNing STRATEgIES}

Unlike traditional methods, communicative approaches over the past 35 years have placed a considerable emphasis on vocabulary learning strategies. These strategies are intended to make students more independent of the teacher and serve as useful tools that can be used both inside and outside classrooms.

Among the central factors that are responsible for the emergence of studies on vocabulary learning strategies, Schmitt (1997) mentions the following: (i) the success/failure of acquiring an L2 very much depends on the student's actions rather than his/her aptitude; (ii) more learning strategies are employed by the L2 learner with vocabulary than with other language skills (e.g., listening) or learning activities (e.g., oral presentations) (Chamot, 1987); (iii) the nature of the lexicon as a component makes it possible to define strategies more precisely, and (iv) vocabulary learning is highly regarded among students (Horwitz, 1988).

Some of the most well-known vocabulary learning strategies are the Keyword Method, guessing from context and dictionary use. The Keyword Method is a type of mnemonic technique based on cognitive processes to enhance retention. It involves two steps, that is, learners first establish an association between the L2 word and an L1 word that is pronounced in a similar way (keyword), and then devise a mental representation that associates the keyword and the target item (Atkinson, 1975). Research on the effectiveness of the Keyword Method indicates its superiority over mechanical rote learning (Sagarra and Alba, 2006) when used by advanced- and lower-level learners. However, this strategy can be rarely used without

\footnotetext{
${ }^{2}$ In this section the number of exposures refers to those encounters with the L2 lexical unit over a period of time and not within the same activity.
} 
a certain amount of training. Additionally, this technique seems to lack long-lasting effects (Brown and Perry, 1991). Guessing from context is a highly recommended strategy not only for reading comprehension but also for learning vocabulary since it requires a greater cognitive effort (Read, 2000). According to Nation (2005), there are some prerequisites that need to be satisfied for successful guessing. First, the learner must be familiar with at least $98 \%$ of the running words in the text, so there will be enough comprehensible context for each unknown item. Second, some training is deemed necessary; this training may focus on linguistic and background knowledge clues. Finally, regarding dictionary-lookup, Oxford and Scarcella (1994) state that looking up a word in a dictionary while reading a text helps improve comprehension. However, an abusive use of this technique leads students to avoid inferring meaning from context. With respect to different types of dictionaries, Baxter (1980) argues that bilingual dictionaries are mostly used by beginning and intermediate L2 students, whereas advanced learners tend to resort to monolingual ones which provide partially contextualized input to the L2 learner through definitions and examples of words in context. In an informal survey, Folse (2004) finds out that of all the teachers that favored some kind of dictionary use, almost $65 \%$ preferred a monolingual dictionary over a bilingual one. The author maintains that little research has been conducted on the efficacy of a certain type of dictionary for lexical learning and that there is no enough empirical evidence to prove that bilingual dictionaries hinder lexical growth and acquisition.

Before teaching vocabulary learning strategies, there are several issues that need to be addressed. First, it may be necessary to convince L2 learners that strategy training may benefit them (Ellis, 1994). Second, when deciding what vocabulary learning strategies to teach, it should be born in mind that strategies are not inherently positive, instead their effectiveness depends on variables such as proficiency level, task language modality, background knowledge, context of learning, source language and target language, and learner characteristics (Chamot and Rubin, 1994). Third, teachers and materials writers should provide learners with enough practice in vocabulary learning strategies, so that students feel confident and proficient enough when using them (Nation, 2001).

\section{The STUDY}

The present study focuses on the six questions listed below and is based on a total of 12 Spanish-language textbooks (plus their teacher's editions) selected for the analysis:

1. Are vocabulary selection criteria explicitly stated?

2. Which type of lexical organization (semantic/thematic) is used more frequently in the presentation of the new vocabulary?

3. Is there variation in the presentation techniques?

4. Is there a balance among the different types of vocabulary practice?

5. Is vocabulary recycled frequently?

6. Is learner autonomy promoted through vocabulary learning strategies and glossaries in the students' L1 at the end of the textbooks? 


\subsection{Instruments}

The empirical study includes a detailed analysis of 12 textbooks (henceforth TB) together with the teacher's guides, produced for the teaching of Spanish as a foreign and second language at three proficiency levels (i.e., beginning, intermediate, and advanced); four TBs were included at each level (see Table 1). In the case of the teacher's books, they were analyzed only to find out whether vocabulary selection criteria had been explicitly stated by the textbook authors.

For admission as data, all 12 TBs were aimed at young adults and adults and were published between 1999 and 2009 by Spanish and American publishers. The TBs were being used at official language schools, private language schools, and study-abroad colleges in Spain and at universities in the United States. Moreover, all TBs were designed for general and regular L2 learning as opposed to specific purposes or intensive L2 study. Furthermore, in order for a TB to be considered valid data for the present study, explicit vocabulary sections not shared with any other L2 components (e.g., grammar, pronunciation) or skills (e.g., reading, listening) were required. A further requirement for inclusion as data was for the TBs to cover at least three language skills apart from the lexical and grammatical areas.

Table 1. Textbooks used in the study

\begin{tabular}{|c|c|c|c|c|c|}
\hline $\begin{array}{l}\text { Titles and } \\
\text { acronyms }\end{array}$ & Authors & Publisher & $\begin{array}{c}\begin{array}{c}\text { Year of } \\
\text { publication }\end{array} \\
\end{array}$ & $\begin{array}{c}\text { Proficiency } \\
\text { level }\end{array}$ & $\begin{array}{c}\text { Vocabulary } \\
\text { methodology }\end{array}$ \\
\hline Avance (A) & C. Moreno and V. Moreno & SGEL & 2004 & Beginning & $\begin{array}{c}\text { The need to } \\
\text { communicate in } \\
\text { Spanish is recognized, } \\
\text { but form also receives } \\
\text { attention. }\end{array}$ \\
\hline $\operatorname{Nexos}(\mathrm{N})$ & $\begin{array}{l}\text { S. Spaine Long, M. } \\
\text { Carreira, S. Madrigal } \\
\text { Velasco, and K. Swanson }\end{array}$ & $\begin{array}{l}\text { Houghton } \\
\text { Mifflin }\end{array}$ & 2009 & Beginning & $\begin{array}{l}\text { Vocabulary sections } \\
\text { present vocabulary in } \\
\text { context; New thematic } \\
\text { vocabulary is practiced } \\
\text { through activities } \\
\text { that progress from } \\
\text { structured to more } \\
\text { open-ended. }\end{array}$ \\
\hline $\begin{array}{l}\text { Español en } \\
\text { Marcha (EEM) }\end{array}$ & $\begin{array}{l}\text { F. Castro Viúdez, P. Díaz } \\
\text { Ballesteros, I. Rodero Díez, } \\
\text { and C. Sardinero Franco }\end{array}$ & SGEL & 2006 & Beginning & No description \\
\hline Vistazos (V) & $\begin{array}{l}\text { B.VanPatten, J. F. Lee, and } \\
\text { T. L. Ballman }\end{array}$ & $\begin{array}{l}\text { McGraw- } \\
\text { Hill }\end{array}$ & 2006 & Beginning & $\begin{array}{l}\text { Each vocabulary } \\
\text { section presents new } \\
\text { active vocabulary } \\
\text { related to the lesson } \\
\text { theme and is followed } \\
\text { by activities that } \\
\text { encourage students to } \\
\text { use the new vocabulary } \\
\text { in context. }\end{array}$ \\
\hline
\end{tabular}




\begin{tabular}{|c|c|c|c|c|c|}
\hline ECO B1 (E) & $\begin{array}{l}\text { C. Romero Dueñas, and A. } \\
\text { González Hermoso }\end{array}$ & Edelsa & 2004 & Intermediate & No description \\
\hline Conexiones (C) & $\begin{array}{l}\text { E. Zayas-Bazán, S. M. } \\
\text { Bacon, D. García, and C. } \\
\text { García }\end{array}$ & $\begin{array}{l}\text { Prentice } \\
\text { Hall }\end{array}$ & 2006 & Intermediate & $\begin{array}{l}\text { A thematically } \\
\text { organized presentation } \\
\text { of words and } \\
\text { expressions follows } \\
\text { the chapter-opening } \\
\text { text. First Vocabulario } \\
\text { primordial provides } \\
\text { a list of review } \\
\text { vocabulary related } \\
\text { to the chapter theme } \\
\text { and presented } \\
\text { without translation. } \\
\text { Vocabulario clave } \\
\text { presents new words } \\
\text { and expressions } \\
\text { organized by parts of } \\
\text { speech and with their } \\
\text { English equivalents. } \\
\text { iCuidado! alerts } \\
\text { students about false } \\
\text { cognates. Aplicación } \\
\text { gives the opportunity to } \\
\text { use the new vocabulary } \\
\text { in meaningful and } \\
\text { communicative } \\
\text { contexts. These } \\
\text { activities range } \\
\text { from guided to } \\
\text { communicative. }\end{array}$ \\
\hline $\begin{array}{l}\text { ¿Qué te parece? } \\
\text { (QTP) }\end{array}$ & $\begin{array}{l}\text { J. Lee, D. J. Young, R. } \\
\text { Bransdorfer, and D. Wolf }\end{array}$ & $\begin{array}{l}\text { McGraw- } \\
\text { Hill }\end{array}$ & 2005 & Intermediate & $\begin{array}{l}\text { The fundamental } \\
\text { organization tool } \\
\text { of the book is a set } \\
\text { of vocabulary and } \\
\text { grammar activities } \\
\text { labelled Ideas para } \\
\text { explorar (IPE). The } \\
\text { vocabulary for each } \\
\text { IPE is comprised of } \\
\text { words that students } \\
\text { need in order to } \\
\text { convey and exchange } \\
\text { information. The new } \\
\text { format for presenting } \\
\text { the meaning of each } \\
\text { word includes using } \\
\text { the word in a context } \\
\text { and providing other } \\
\text { forms of the word. }\end{array}$ \\
\hline De Perlas (DP) & $\begin{array}{l}\text { A. Labarca, E. A. } \\
\text { Rodríquez, and O. G. } \\
\text { González }\end{array}$ & Wiley & 1999 & Intermediate & No description \\
\hline A Fondo (AF) & $\begin{array}{l}\text { M. L. Coronado González, } \\
\text { J. García González, and A. } \\
\text { Zarzalejos Alonso }\end{array}$ & SGEL & 2005 & Advanced & No description \\
\hline
\end{tabular}




\begin{tabular}{|l|l|l|l|l|l|}
\hline Sueña 3 (S) & $\begin{array}{l}\text { M. A. Álvarez Martínez, M. } \\
\text { V. de la Fuente Martínez, I. } \\
\text { Giraldo Silverio, F. Martín } \\
\text { Martín, B. Sanz Sánchez, } \\
\text { and M. J. Torrens Álvarez }\end{array}$ & 2001 & Advanced & $\begin{array}{c}\text { The book focuses on } \\
\text { those students that still } \\
\text { need to enlarge their } \\
\text { L2 vocabulary. The } \\
\text { main aim is to develop } \\
\text { the communicative } \\
\text { competence. The book } \\
\text { ends with a Glosario } \\
\text { that contains the } \\
\text { vocabulary taught } \\
\text { and it is translated } \\
\text { into five languages. } \\
\text { The Glosario is not a } \\
\text { dictionary but a useful } \\
\text { tool for the teacher } \\
\text { and the student since } \\
\text { it comprises the basic } \\
\text { vocabulary of each } \\
\text { lesson. }\end{array}$ \\
\hline Opiniones (O) & $\begin{array}{l}\text { V. Rodrigo, F. Lluna-Mateu, } \\
\text { and C. Schlig }\end{array}$ & $\begin{array}{l}\text { Pearson- } \\
\text { Prentice- } \\
\text { Hall }\end{array}$ & 2005 & Advanced & $\begin{array}{c}\text { It exposes students to } \\
\text { authentic language }\end{array}$ \\
\hline $\begin{array}{l}\text { Repase y Escriba } \\
\text { (RYE) }\end{array}$ & $\begin{array}{l}\text { M. Cauteli Dominicis, and J. } \\
\text { Reynolds }\end{array}$ & Wiley & 1999 & Advanced & \begin{tabular}{c} 
No description \\
\hline
\end{tabular} \\
\hline
\end{tabular}

The various vocabulary exercises and activities included in the TBs were analyzed following a specific typology devised for this study based on the students' relative degree of control over their expected answers ${ }^{3}$. A typology designed on the basis of factors such as attention, depth of processing, and word retrievals was not employed since the results of empirical studies have not drawn definite conclusions on the most effective factor(s) regarding L2 vocabulary retention in long-term memory.

This typology consisted of the following five activity types: (i) mechanical exercise: explicit comprehension of lexical items is not necessary as there is only one correct answer (e.g., completing a word with the missing vowel and/or consonant letters); (ii) closed exercise: a greater degree of comprehension of the target vocabulary is needed, yet there is still only one valid answer (e.g., fill-in-the-blank exercises); (iii) open activity: students are required to understand the target vocabulary; there are two or more valid answers and there may or may not be explicit information gaps (e.g., question-and-answer activities based on the target vocabulary, giving definitions of target vocabulary); (iv) communicative activity: there is an open answer and/or a lexical choice that is required to complete the activity, along with explicit information gaps; the instructions ask students to interact with each other to achieve a predetermined final outcome which may not be reached individually (e.g., writing advertisements in pairs using the vocabulary provided); and (v) ambiguous activity: there is a single exercise or activity which contains features of more than one of the four categories described above.

\footnotetext{
${ }^{3}$ This typology is an adaptation of Aski’s (2003).
} 


\subsection{Results}

The results of the analysis indicate that only one of the teacher's editions under scrutiny $(8.33 \%)$ provides the specific source from which the vocabulary was obtained ("Frecuencia de uso y estudio con especial aplicación a la enseñanza del español como lengua extranjera, H004/2000", Sueña 3), the rest of the teacher's guides do not explicitly state their vocabulary selection criteria. In other words, factors such as students' needs and interests, word frequency, and their language level do not seem to have been explicitly addressed by the TB writers.

Regarding the introduction of the new vocabulary, $58.59 \%$ of the teaching units/lessons analyzed include explicit presentation of the items. The general tendency of the advanced TBs is to reduce the percentage of explicit presentation as compared with their intermediate and beginning counterparts $(25 \%$ in advanced TBs, $74.38 \%$ in intermediate TBs, and $76.4 \%$ in beginning TBs). Seventy-five percent of the TBs that include explicit presentation of the new lexis were produced by American publishers whose main target audience consists of English-speaking learners of Spanish as a foreign language in the United States.

As for the organization of the explicit presentation of the new vocabulary, most TBs resort to semantic sets to the detriment of thematic groupings (see graph 1). In the description of the vocabulary methodology only two books, Nexos and Conexiones, acknowledge the

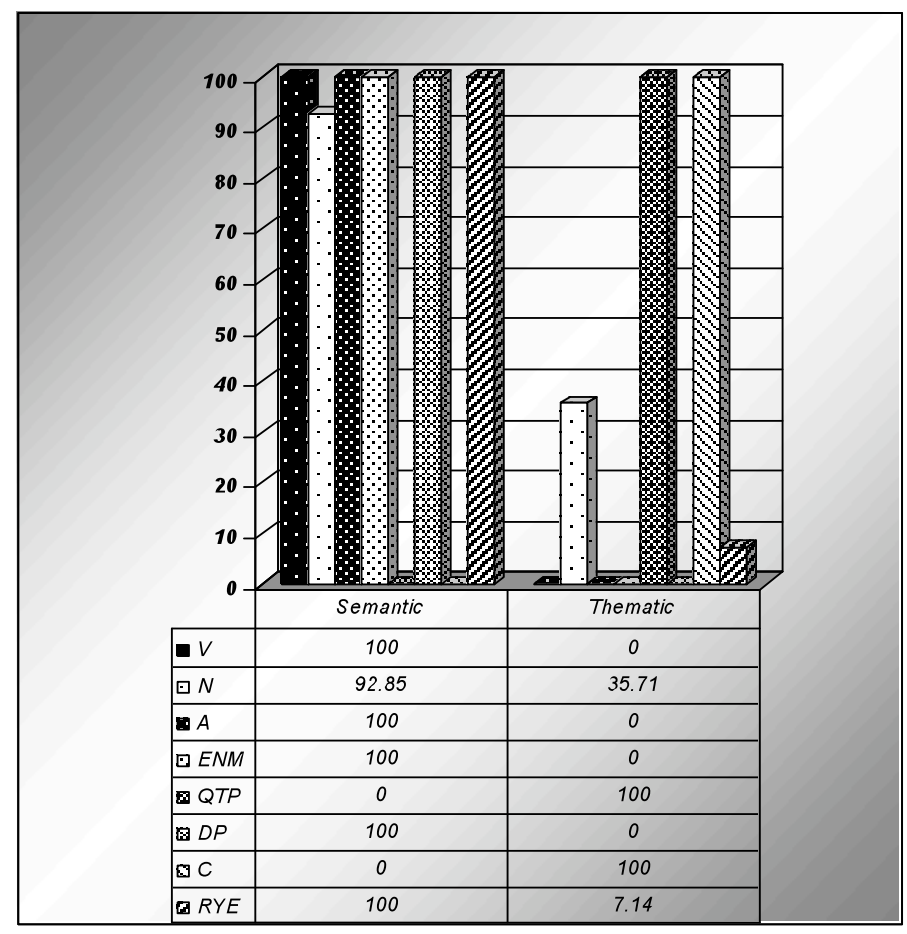

Graph 1. Organization of explicit presentation 
presence of thematically-organized vocabulary (see Table 1). This description just confirms the scarcity of thematic clusterings when organizing the new lexicon. In addition, half of the TBs that present the new vocabulary in an explicit way organize it through semantic sets and are beginning level TBs.

Graph 2 shows that a variety of presentation techniques are employed in the introduction of new lexical items; the use of texts $(50.83 \%)$, translations $(32.14 \%)$, visuals $(28.05 \%)$, word lists (23.95\%), and explanations (22.9\%) were the most recurrent techniques. Translation is solely present in TBs produced by American publishers for the teaching of Spanish as a foreign language. With respect to the different presentation techniques and the proficiency levels under study, graph 2 indicates that the use of visuals without texts is restricted to beginning TBs. Introducing new items through texts is mostly preferred by the writers of intermediate and advanced TBs, whereas translation is more frequent in beginning TBs compared to the other text levels. Lastly, other techniques such as word lists, definitions/ descriptions, synonyms, and explanations play a more relevant role in intermediate TBs than in their beginning and advanced counterparts.

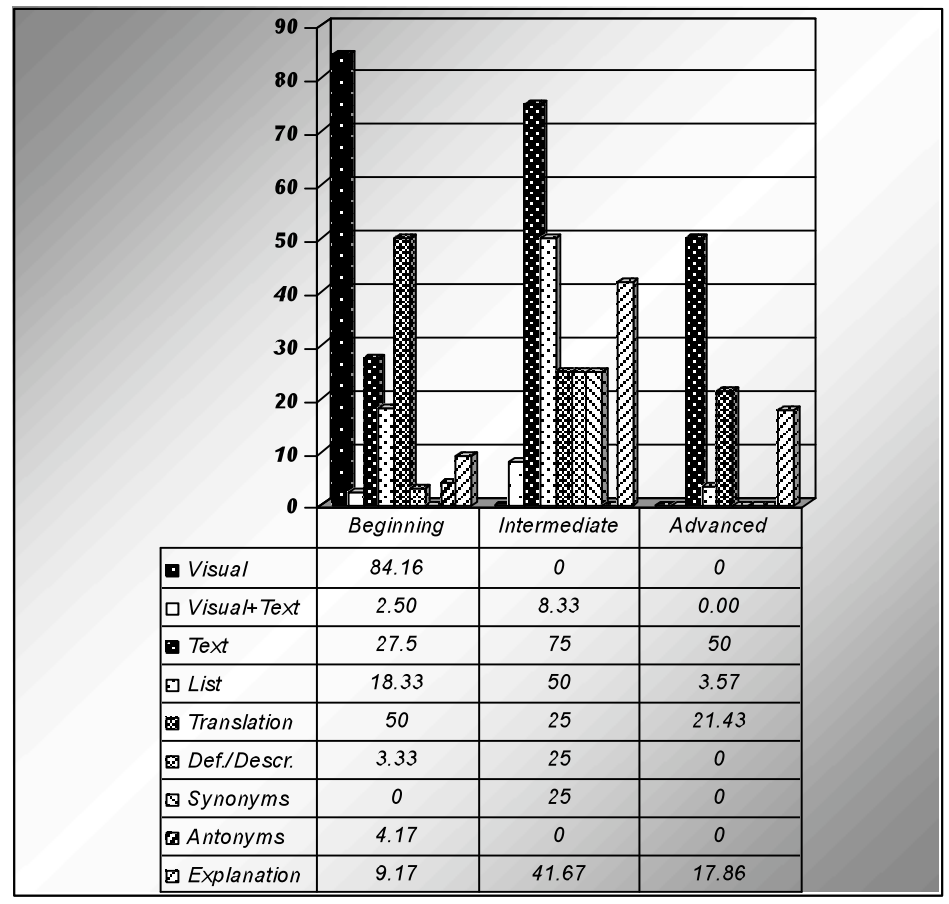

Graph 2. Presentation techniques

In terms of vocabulary practice, the percentage of teaching units that include the practice of the new vocabulary items amounts to $98.86 \%$ and it is very similar at all three proficiency levels under study ( $96 \%$ in beginning TBs, $100 \%$ in intermediate TBs, and $100 \%$ in advanced TBs). The practice itself is mostly comprised of closed exercises $(57.35 \%)$ and open activi- 
ties $(32.87 \%)$, whereas communication activities (4.88\%) and mechanical exercises $(1.42 \%)$ are scarce (see graph 3 ). This paucity of communicative activities is also reflected in the description of the vocabulary methodology (see Table 1) as only two TBs, Conexiones and Sueña 3, state that activities range from guided to communicative and that the main aim of the book is to develop communicative competence, respectively.

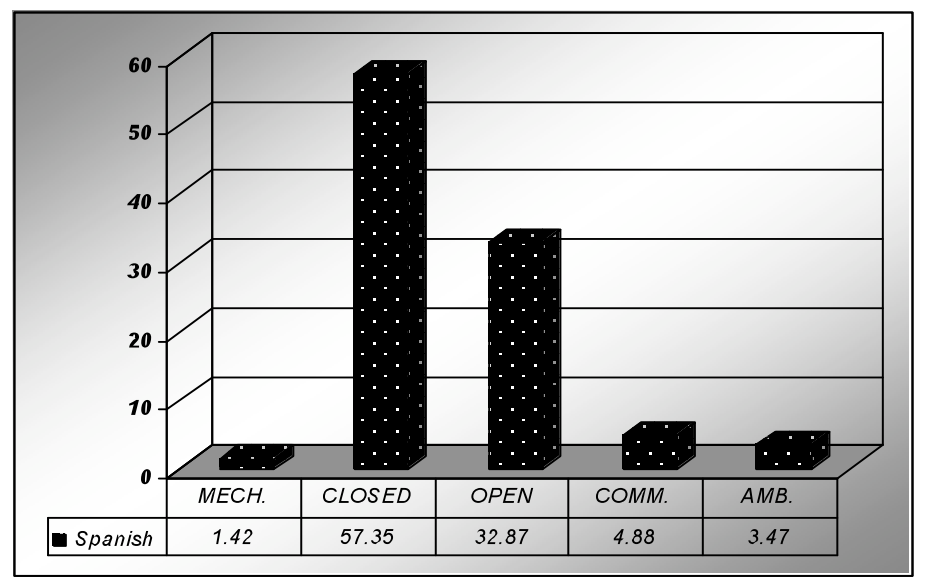

Graph 3. Vocabulary practice

Vocabulary is recycled in $33.31 \%$ of the analyzed teaching units. An increase in the proficiency level of the TBs correlates with an increase in the number of teaching units that review the vocabulary already taught $(19.24 \%$ in beginning TBs, $25 \%$ in intermediate TBs, and $55.7 \%$ in advanced TBs). No specific mention is made to recycling in the vocabulary methodology (see Table 1).

Finally, as for other related lexical aspects under study, it was found that the percentage of sections that contain vocabulary learning strategies $(4.21 \%)$ is even meager than in the case of vocabulary recycling. No information regarding vocabulary learning strategies appears in the section vocabulary methodology (see Table 1). Furthermore, word lists with L1 translation equivalents at the end of the TB are present in half of the beginning and advanced TBs and in all of the intermediate TBs. Seventy-five percent of the TBs that include vocabulary lists with their L1 translations at the end of the TBs were produced by American publishers (Houghton, McGraw Hill, Prentice Hall, Wiley, and Pearson Prentice) for the teaching of Spanish as a foreign language. Only one TB (Sueña 3) under scrutiny explicitly recognizes the presence of a Glosario in the TB (see Table 1). This contrasts with the high number of TBs that contain one at the end of the book.

\section{Discussion}

Starting with the selection criteria, the findings of the analysis reflect the paucity of vocabulary selection criteria. There is a high probability that in the TBs in which the au- 
thors did not explicitly state those criteria, a random selection of the new vocabulary items was performed.

As for the explicit presentation of new lexical items, its smaller presence in the advanced TBs when compared to those at the intermediate and beginning levels could have been motivated by the fact that TB writers may have assumed that advanced level learners no longer need those presentation techniques due to their overall higher level of proficiency. The explicit introduction of new vocabulary items in $75 \%$ of the TBs produced by American publishers may have its origin in that these texts address foreign-language learners of Spanish in the United States. Considering that foreign language students' contact with the target language is often restricted to the classroom and they hardly have opportunities to clarify the meanings of new items outside the classroom, it is likely that the TB writers in this particular learning context decided to stress the relevance of explicit presentation techniques.

The overuse of semantic sets in the organization or arrangement of the explicit introduction of new lexical items seems to follow a widespread belief that these groupings actually help learners remember the words and their meanings. Likewise, materials writers, teachers, and curriculum designers tend to resort to semantic sets since they are assumed to be an easy way to arrange second-language materials. Thus, from a methodological perspective, semantic clusterings suit not only a structure-based approach where these semantic sets fit into written substitution drills, but also a more learner-centered approach where words from these clusters fit within the situations, notions, or functions being taught (Folse, 2006). However, the extant research (Papathanasiou, 2009; Tinkham, 1993, 1997; Waring, 1997) evinces that organizing the new lexicon through semantic sets actually hinders and impedes learning. In terms of the proficiency levels of the analyzed TBs and the type of groupings, the preference for semantic sets in beginning TBs may respond to the assumption that the inclusion of lexical items that belong to the same grammatical category facilitates L2 vocabulary learning. Nonetheless, the existing literature on L2 vocabulary acquisition has not proved this notion among lower-level learners.

Regarding the variety of presentation techniques found in the TBs under analysis, most writers resort to texts, translations into the students' L1, and visuals. The high percentage $(50.83 \%)$ of teaching units that introduce the new vocabulary through texts could be explained by the influence of communicative approaches that promote the use of context to make the process of learning vocabulary more natural. Nonetheless, as experimental studies (Nagy, Herman, and Anderson, 1985) have shown, inferring meaning from context may be less effective than the explicit presentation of the new vocabulary since context clues may be rather restrictive devices to predict word meaning; thus, it may not foster retention of new meanings (Pressley, Levin, and McDaniel, 1987). Besides, translation as a presentation technique could be accounted for by the fact that part of the TBs were designed for the teaching of Spanish as a foreign language in the United States. It may have been the writers' intention to make the meaning of new items clear through L1 equivalents since the opportunities for these students to learn their meaning outside the classroom tend to be limited.

In relation to the presentation strategies and the proficiency level, the exclusive use of visual resources and the major presence of translations in beginning TBs could be explained by the fact that these two presentation techniques do not expose the students to the L2, and consequently simplify the introduction of new lexical items at the beginning level. On the other hand, the presentation techniques that abound in intermediate books (i.e., text, word 
list, definition/description, synonym, explanation) imply a greater contact with the target language.

Vocabulary practice is mostly composed of closed exercises apart from a discrete presence of open activities. Rixon (2000: 67) describes this situation when she states that "many textbooks include activities that involve manipulating language in a rather mechanical way [...]. Many vocabulary activities involve little more than slot-filling within an obvious context." Likewise, Tomlinson (2008) points out that teaching materials do not reflect the process of acquiring an L2, since most vocabulary practice does not extend beyond memorization, repetition, substitution, and transformation. In this study the scarcity of communicative activities in the TBs could have a twofold motivation:

a) the use of a specific definition of communicative activity,

b) communicatively-oriented approaches have changed in the last 20 years; between 1990 and 2000, approximately, these approaches focused largely on achieving a balance between form and fluency, whereas in the last decade or so an increased emphasis on form may be detected, particularly in terms of textbook design rather than teaching orientation. Since the TBs under scrutiny were published between 1999 and 2009, it is likely that this focus is reflected therein.

The amount of vocabulary recycling is clearly inadequate. Research has emphasized the need to expose L2 learners to an average of six to ten encounters with the same vocabulary item in order for that word to be retained in long-term memory. Tomlinson (2008) (see Arnold and Rixon, 2008; Dat, 2008) maintains that in spite of the effective number of exercises provided for students to practice new vocabulary within every unit, the need for recycling the language being taught is overlooked in TBs. The major presence of sections that review vocabulary in intermediate and advanced TBs is not supported by empirical studies. Instead, this tendency in the analyzed TBs may be related to the shared belief among materials writers that the introduction of vocabulary items needs to increase as the learners' proficiency level also increases (Brown, 2011).

Concerning learner autonomy, it is hardly promoted through vocabulary learning strategies, whereas glossaries in the students' L1 at the end of the TBs are a recurrent tool in the TBs employed in this study. As stated earlier, their inclusion may find its origin in the place of publication since $75 \%$ of the TBs that resort to them were published in the United States.

\section{Conclusions ANd PEdagogical implications}

Since vocabulary selection criteria are not specified in most of the analyzed teacher's editions, it may be concluded that the writers' selection of the vocabulary to be taught is rather inconsistent. This absence of explicit criteria is denounced by Rixon (2000: 56) who states that "much of the thinking and planning becomes embedded, even buried, in the materials on the page. In the teacher's books that accompany these courses, authors tend to be rather silent on the subject of the selection and ordering of the language content of their syllabuses and they say particularly little about vocabulary in this regard." 
Apart from the variety of presentation techniques found in the TBs, their place of publication and proficiency level exert influence on the introduction of target items. The TBs produced by American publishers for the teaching of Spanish as a foreign language in the United States usually include more teaching units where the new lexis is introduced explicitly and make a greater use of the students' L1 as a presentation strategy. Additionally, in beginning TBs there is a strong presence of $\mathrm{L} 1$ translation equivalents together with the exclusive employment of visual support without text.

L2 vocabulary teaching in the TBs studied tends to be rather traditional. Vocabulary practice for the most part is based on closed exercises and open activities, while communicative activities are almost absent. Moreover, vocabulary learning strategies as fostered by communicative approaches, partly due to their role in promoting learner autonomy, are hardly found in the books.

The results of recent research into the teaching and learning of vocabulary in an L2 have not been taken into consideration in most of the TBs analyzed. Research has encouraged the introduction of new vocabulary items through thematic sets so as to foster word learning and retention in long-term memory. In this study, it has been shown that most of the TBs resort to semantic groups rather than thematic clusters. Furthermore, the sections that review vocabulary are clearly insufficient, despite the fact that empirical studies have emphasized the need to expose L2 learners to several encounters with target items to enhance word learning.

The findings of this study have significant pedagogical implications, so that specific teaching materials, such as TBs for the teaching of L2 Spanish, may actually become more effective tools. First, vocabulary selection criteria should be made explicit to avoid unsystematic or pedagogically useless choices. Second, in the organization of the new target items thematic groups merit a more relevant role, while semantic sets are recommended at the recycling stage (Nation, 1990). Third, a more balanced number of controlled versus communicative activities is desirable, so that L2 learners may learn vocabulary in a less artificial manner, namely, through input and output activities that are more sustained and meaningful to them. Fourth, TB writers are advised to regularly revisit vocabulary items at all levels of proficiency. Several encounters with the same item will not only help secure vocabulary knowledge in the learners' memory, so that lexical items may be accessed automatically, but also introduce additional features of the same word (e.g., lexical collocations). Lastly, learner autonomy should be promoted through the inclusion of L1 glossaries as well as sections that provide students with effective vocabulary learning strategies.

\section{REFERENCES}

Anderson, J. P. and Jordan, A. M. (1928). "Learning and retention of Latin words and phrases", in Journal of Educational Psychology, 19: 485-496.

Arnold, W. and Rixon, S. (2008). "Materials for teaching English to young learners", in B. Tomlinson (ed.), English Language Learning Materials. London: Continuum International Publishing Group, 38-58.

Aski, Y. M. (2003). "Foreign language textbook activities: Keeping pace with second language acquisition research", in Foreign Language Annals, 36: 57-65. 
Atkinson, R. C. (1975). "Mnemotechnics in second-language learning”, in American Psychologist, 30: $821-828$.

Baxter, J. (1980). “The dictionary and vocabulary behavior: A single word or a handful?", in TESOL Quarterly, 14: 325-336.

Brown, D. (2011). "What aspects of vocabulary knowledge do textbooks give attention to?", in Language Teaching Research, 15: 83-97.

Brown, T. S. and Perry, F. L. (1991). "A comparison of three learning strategies for ESL vocabulary acquisition", in TESOL Quarterly, 25: 17-32.

Carter, R. (1987). "Vocabulary and second/foreign language teaching", in Language Teaching, 20: $3-16$.

Chamot, A. U. (1987). "The learning strategies of ESL students", in A. Wenden and J. Rubin (eds.), Learner Strategies in Language Learning. New York: Prentice Hall, 71-83.

Chamot, A. U. and Rubin, J. (1994). "Comments on Janie Rees-Miller's 'A critical appraisal of learner training: Theoretical bases and teaching implications.' Two readers react...", in TESOL Quarterly, 28: 771-776.

Craik, F. I. M. and Tulving, E. (1975). "Depth of processing and the retention of words in episodic memory", in Journal of Experimental Psychology, 104: 268-294.

Dat, B. (2008). "ELT materials used in Southeast Asia", in B. Tomlinson (ed.), English Language Learning Materials. London: Continuum International Publishing Group, 263-280.

Ellis, R. (1994). "Factors in the incidental acquisition of second language vocabulary from oral input: A review essay", in Applied Language Learning, 5: 1-32.

Folse, K. S. (2004). Vocabulary Myths. Ann Arbor: The University of Michigan Press.

Folse, K. S. (2006). "The effect of type of written exercise on L2 vocabulary retention", in TESOL Quarterly, 40: 273-293.

Gairns, R. and Redman, S. (1986). Working with Words. Cambridge: Cambridge University Press.

Griffin, G. F. (1992). Aspects of the Psychology of Second Language Vocabulary List Learning. Unpublished doctoral dissertation, University of Warwick, Warwick.

Haynes, M. and Baker, I. (1993). "American and Chinese readers learning from lexical familiarizations in English text", in J. Coady and T. Huckin (eds.), Second Language Reading and Vocabulary Learning. Norwood, NJ: Ablex, 130-152.

Horwitz, E. K. (1988). "The beliefs about language learning of beginning university foreign language students", in The Modern Language Journal, 72: 283-294.

Hulstijn, J. (1992). "Retention of inferred and given word meanings: Experiments in incidental vocabulary learning", in P. J. L. Arnaud and H. Béjoint (eds.), Vocabulary in Applied Linguistics. London: Macmillan Academic and Professional Limited, 113-125.

Hulstijn, J. and Laufer, B. (2001). "Some empirical evidence for the Involvement Load Hypothesis in vocabulary acquisition”, in Language Learning, 51: 539-558.

Jourdenais, R., Ota, M., Stauffer, S., Boyson, B. and Doughty, C. (1995). "Does textual enhancement promote noticing?: A think aloud protocol analysis", in R. Schmidt (ed.), Attention and Awareness in Foreign Language Learning. Honolulu, HI: University of Hawaii, Second Language Teaching and Curriculum Center, 183-216.

Kachroo, J. N. (1962). "Report on an investigation into the teaching of vocabulary in the first year of English", in Bulletin of the Central Institute of English, 2: 67-72.

Kim, Y. (2011). "The role of task-induced involvement and learner proficiency in L2 vocabulary acquisition", in Language Learning, 61: 100-140. 
Laufer, B. and Hulstijn, J. (1998, March). What Leads to Better Incidental Vocabulary Learning: Comprehensible Input or Comprehensible Output? Paper presented at Pacific Second Language Research Forum (PacSLRF), Tokyo.

Laufer, B. and Shmueli, K. (1997). "Memorizing new words: Does teaching have anything to do with it?", in RELC Journal, 28: 89-108.

Lawley, J. (2010). "Conspicuous by their absence: The infrequency of very frequent words in English as a foreign language (EFL) materials", in R. Chacón-Beltrán, C. Abello-Contesse and M. M. Torreblanca-López (eds.), Insights into Non-native Vocabulary Teaching and Learning. London: Multilingual Matters, 145-155.

Lewis, M. (1993). The Lexical Approach. The state of ELT and the way forward. London: Language Teaching Publications.

Lewis, M. (1997). Implementing the Lexical Approach. London: Language Teaching Publications.

Lewis, M. and Hill, J. (1985). Practical Techniques for Language Teaching. London: Language Teaching Publications.

Lotto, L. and de Groot, A. (1998). "Effects of learning method and word type on acquiring vocabulary in an unfamiliar language", in Language Learning, 48: 31-69.

Luppescu, S. and Day, R. (1993). "Reading, dictionaries, and vocabulary learning", in Language Learning, 43: 263-287.

McKeown, M. and Curtis, M. (1987). The Nature of Vocabulary Acquisition. Hillsdale, NJ.: Lawrence Erlbaum Associates.

Milton, J. (2009). Measuring Second Language Vocabulary Acquisition. Bristol: Multilingual Matters.

Nagy, W. E., Herman, P. A. and Anderson, R. C. (1985). "Learning words from context", in Reading Research Quarterly, 20: 233-253.

Nation, I. S. P. (1990). Teaching and Learning Vocabulary. New York: Newbury House.

Nation, I. S. P. (2001). Learning Vocabulary in Another Language. Cambridge: Cambridge University Press.

Oxford, R. L. and Scarcella, R. C. (1994). "Second language vocabulary learning among adults: State of the art in vocabulary instruction", in System, 22: 231-243.

Papathanasiou, E. (2009). "An investigation of two ways of presenting vocabulary". ELT Journal, available from doi:10.1093/elt/ccp014.

Paribakht, T. and Wesche, M. (1997). "Vocabulary enhancement activities and reading for meaning in second language vocabulary acquisition", in J. Coady and T. Huckin (eds.), Second Language Vocabulary Acquisition. Cambridge: Cambridge University Press, 174-200.

Pimsleur, P. (1967). "A memory schedule", in Modern Language Journal, 51: 73-75.

Postman, L. (1961). "The present status of interference theory", in C. N. Cofer (ed.), Verbal Learning and Verbal Behaviour. New York: McGraw-Hill, 152-179.

Pressley, M., Levin, J. R. and McDaniel, M. A. (1987). "Remembering versus inferring what a word means: Mnemonic and contextual approaches", in M. G. McKeown and M. E. Curtis (eds.), The Nature of Vocabulary Acquisition. Hillsdale, N. J.: Lawrence Erlbaum Associates, 107-127.

Prince, P. (1996). "Second language vocabulary learning: The role of context versus translations as a function of proficiency", in The Modern Language Journal, 80: 478-493.

Read, J. (2000). Assessing Vocabulary. Cambridge: Cambridge University Press.

Richards, J. C. (1976). "The role of vocabulary teaching", in TESOL Quarterly, 10: 77-89. 
Richards, J. C. and Schmidt, R. (2010). Longman Dictionary of Language Teaching and Applied Linguistics. London: Pearson Education Limited.

Rixon, S. (2000). "Where do the words in EYL textbooks come from?", in S. Rixon (ed.), Young Learners of English: Some Research Perspectives. London: Longman, 55-71.

Sagarra, N. and Alba, M. (2006). "The key is in the keyword: L2 vocabulary learning methods with beginning learners of Spanish", in The Modern Language Journal, 90: 228-241.

Saragi, T., Nation, I. S. P. and Meister, G. F. (1978). "Vocabulary learning and reading", in System, 6: 72-78.

Schatz, E. K. and Baldwin, S. R. (1986). "Context clues are unreliable predictors of word meanings", in Reading Research Quarterly, 21: 439-453.

Schmitt, N. (1997). "Vocabulary learning strategies", in N. Schmitt and M. McCarthy (eds.), Vocabulary: Description, Acquisition, and Pedagogy. Cambridge: Cambridge University Press, 199-227.

Seibert, L. C. (1927). "An experiment in learning French vocabulary", in Journal of Educational Psychology, 18: 294-309.

Stahl, S. A. and Fairbanks, M. M. (1986). "The effects of vocabulary instruction: A model-based meta-analysis", in Review of Educational Research, 56: 72-110.

Thornbury, S. (2002). How to Teach Vocabulary. Essex, England: Longman.

Tinkham, T. (1993). "The effect of semantic clustering on the learning of second language vocabulary", in System, 21: 371-380.

Tinkham, T. (1997). "The effects of semantic and thematic clustering on the learning of second language vocabulary", in Second Language Research, 13: 138-163.

Tomlinson, B. (2008). English Language Learning Materials. London: Continuum International Publishing Group. 